\title{
The Brachiopoda collected by the "Huxley" from the North Side of the Bay of Biscay, in August, 1906.
}

By

Alexander Reynell.

OF the three species of Brachiopoda found, two, Magellania cranium and M. septigera, are found in the British list. The third species, Mühlfeldtia truncata, has not, as far as I can discover, previously been recorded from so high a latitude, Turton's Torbay locality being very doubtful.

\section{BRACHIOPODA.}

\author{
ARTICULATA. \\ TEREBRATULID曆. \\ Magellania, Bayle.
}

(1) Magellania cranium, Müller.

Terebratula cranium, Müller, 1776. Zool. Dan. Prodr., p. 249.

Anomia cranium, Gmelin, 1789. Syst. Nat., édit. xiii, p. 3347.

Waldheimia cranium, Reeve, 1860. Conch. Icon., pl. iii, fig. 6 .

Magellania (Macandrevia) cranium, P. Fischer et Ehlert, 1891. Trav. and Talis. Expedit., Brach., p. 73, pl. v, figs. $10 a-10$ s.

Distributed from Greenland and Norway to the south-west of France, according to Jeffreys. A. Adams records it from Northern Asia and Japan.

Mons. Dautzenberg kindly identified this species.

Station V. 109 fathoms. One living.

" XII. 246 fathoms. One living.

(2) Magellania septigera, Lovén.

Terebratula septigera, Lovén, 1846. Index Moll. Scand., p. 29.

Waldheimia septigera, Davidson, 1855. Ann. and Mag. Nat. Hist. [II], vol. xvi, 1855 .

Terebratula septata, Jeffreys, 1878. Proc. Zool. Soc., London, p. 407, pl. xxiii, fig. 1. 
- There seems to be some doubt as to whether this species is the same as the Terebratula septata of Philippi. Both Jeffreys and Locard are of the opinion that it is, but Fischer and Ehlert do not even mention Philippi's name. I, under the circumstances, think it the wisest plan to follow the latter authorities. This species seems to be distributed in the eastern part of the North Atlantic, from Norway and the Hebrides and Shetland Islands to the West Coast of Africa and the Canary Islands.

Station XI. 146 fathoms. One small, living.

" XIII. 412 fathoms. Eleven living.

MüHlfeldtia, Bayle.

Mühlfeldtia truncata (Linné).

Anomia truncata, Linné, 1767. Syst. Nat., édit. xii, p. 1152, No. 229 .

Terebratula truncata, Philippi, 1836. Enum. Moll. Sicil., I, p. 95, pl. vi, fig. 12 .

Muihlfeldtia truncata, P. Fischer and D. P. Ehlert, 1891. Trav. et Talis. Brachiopoda, p. 80 , pl. vii, figs. $11 a-11 t$.

This species is recorded as being very common in the Mediterranean, and has been found in the Bay of Biscay, at many stations off Cape Finisterre, the North of Spain, and has been dredged off the Morocco coast, and the Canary Isles. Turton's record of a specimen from Torbay is generally considered doubtful, as far as being a proof of its living in the British area is concerned.

Station VII. $\dot{\overrightarrow{144}}$ fathoms. Three living.

\section{BIBLIOGRAPHY}

Fischer, P., and Ehlert, D. P.-Brachiopodes de l'Atlantique Nord, 1892. Résultats des Campagnes Scientifiques accomplies sur son Yacht par Albert Ier Prince de Monaco.

Jeffreys, J. Gwyn.-On the Mollusca procured during the Lightning and Porcupine Expedition, 1868-70. Part I, Proc. Zool. Soc., Lond., 1878.

Locard, A.-Brachiopods. Résultats Scientifiques de la Campagne du Caudan dans le Golfe de Gascogne, August-September, 1895, 1896.

Many Brachiopods are, of course, included in the older works dealing with the Mollusca as detailed in the bibliography of that group on pages 387 and 388 . 